\title{
Field Investigation on Anthropogenic Impacted Lowland Riparian Zones
}

\author{
Darrien Y. S. Mah ${ }^{1 *}$, Kelvin K. K. Kuok ${ }^{2}$ \\ ${ }^{1}$ Department of Civil Engineering, Faculty of Engineering, Universiti Malaysia Sarawak, Kota Samarahan, Malaysia \\ ${ }^{2}$ Faculty of Engineering, Computing and Science, Swinburne University of Technology, Sarawak, Malaysia \\ Email:ysmah@feng.unimas.my, kkuok@swinburne.edu.my
}

Received December 6, 2012; revised January 7, 2013; accepted January 17, 2013

\begin{abstract}
A functioning riparian zone is very beneficial to the environment. However, most of the riparian zones have been disturbed by man-made implications these days. Public awareness about the issues of environmental conservation including riparian zones is needed by providing information on critical areas. Therefore, a novel framework is presented here to reveal how well a riparian zone adopts to changes. This paper highlights the field investigation of an altered riparian system along Maong River in Kuching, Sarawak. Investigation of the general riparian health is followed by the studies of its contributing attributes - vegetation cover, human activities and groundwater level, have been carried out. The methods are practicable in harnessing understanding and knowledge of riparian conditions. For a disturbed riparian zone, the findings indicate that $50 \%-60 \%$ of the study areas are categorized as healthy or functioning riparian systems, at the same time, correlate the influences of the three afore-mentioned attributes.
\end{abstract}

Keywords: Groundwater; Maong River; Measurement; Rapid Assessment; Urban; Vegetation

\section{Introduction}

Anthropogenic endeavours have long influenced the riparian zones. However, living organisms adapt to disturbance regime over broad spatial-temporal scales [1]. Therefore, an understanding of the mentioned adaptation reflects the pulses of riparian zones and rivers due to changes in anthropogenic activities [2]. This has called for an exploration of an altered riparian system in a Maong River in Kuching, Sarawak.

Maong River is a tributary of and tidally influenced by its main-stem Sarawak River. Naturally, the river was a nipah-fringed river (see Figure 1), where nipah palms (Nypa fruticans) were the dominant vegetation. Nipah is found upstream of mangrove, which strives in freshwater-brackish reaches of a river [4]. However, human settlements were erected along this river over the past 100 years, reducing the nipah system to merely grasses and bushes.

\section{Case Study}

Nipah system is unique on its own because the plants need both freshwater and salt water to survive. The presence of salt disables other freshwater species to take over its establishment, at the same time, the constant

*Formerly with River Engineering and Urban Drainage Research Centre (REDAC), Universiti Sains Malaysia, Penang, Malaysia. flows of freshwater in the form of high groundwater table maintains its vitality [5-7]. When human removes the nipah for physical development, this process alters the freshwater flows. For the denudation of the water-retaining nipah system reduces the water holding ability of the soil and eventually causes the groundwater level to drop $[8,9]$.

The remnants of riparian zones along Maong River are taking over by secondary growth extending $50-100 \mathrm{~m}$ from the river banks (see Figure 2(b)). For comparison, the 100-year old painting in Figure 2(a) is showing the primary growth of tall nipah palms. Apparently, in the late 1880 s where human settlement of colonial era was significant, grasses appeared in the painting after human clearing of lands.

Because of such a drastic change, it is the intension of this paper to explore the current conditions of riparian zones along Maong River. By understanding and knowing riparian health or function, it allows communities to identify concerns and to proactively address specific land use issues [10].

\section{Methods}

Stretches of Maong River beside the Wee and Wee Garden is chosen, for its upper and lower boundaries are easily identifiable and findable for repeat assessments. Areas of concern are designated into polygons of $100 \times$ 


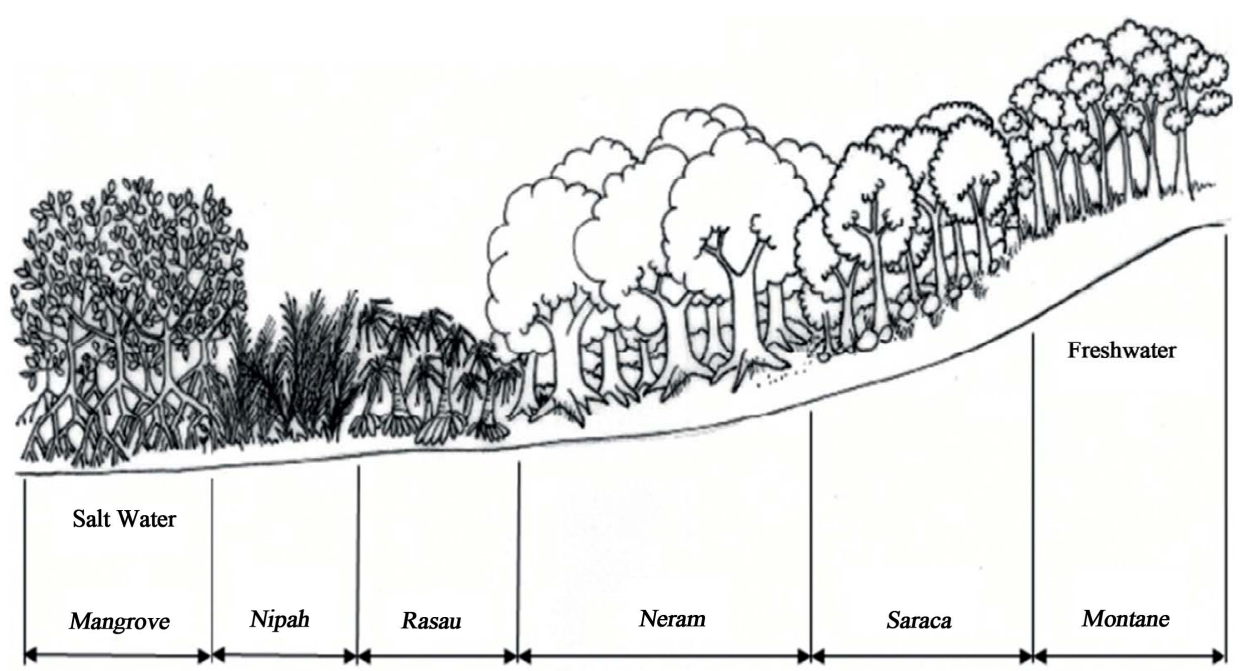

Figure 1. Typical Riparian Habitat in Southeast Asia [3].

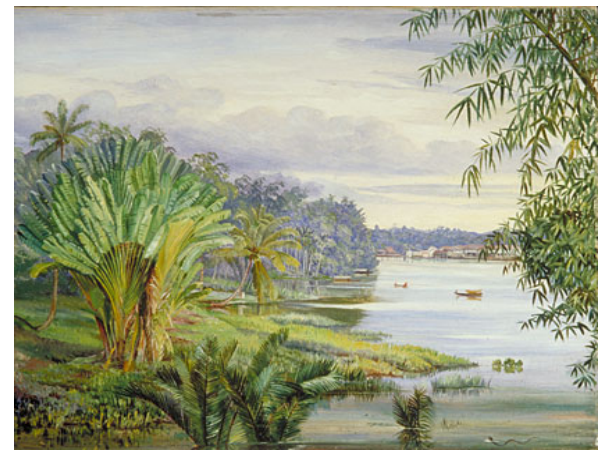

(a)

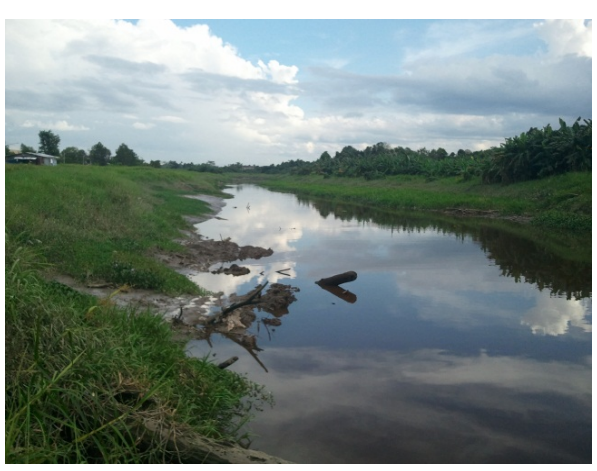

(b)

Figure 2. Riparian Zones, (a) view of Sarawak River (1880s) ${ }^{a}$ and (b) view of Maong River (2012).

$100 \mathrm{~m}$ in dimension for field investigation and sampling purposes (see Figure 3). There are a total of 27 polygons selected for representation of its situations in the riparian system under study. All polygons should touch the water edge as much as possible. The composition in each polygon varies with two distinct characteristics of vegetation cover and human activities.

Two methods are used here. First, a rapid assessment using Proper Functioning Condition (PFC) method [11, $12]$ is carried out. Each polygon is determined of its conditions whether it is functioning or non-functioning. Second, field measurement of three attributes - vegetation cover, human activities and groundwater level are collected in each polygon to compare with the corresponding PFC data set.

\section{Proper Functioning Condition}

There are many ways of assessing the conditions of a riparian system. For an altered system, where the indi-

\footnotetext{
${ }^{a}$ Painting of Marianne North who travelled the globe between 1871 and 1885 to record the world's flora. The painting is now displayed in the Kew Royal Botanic Garden, UK.
}

genous plants were fully stripped off, it is fair to take a different approach than the conventional $[13,14]$. The Maong River is assessed based on the characteristics of an ecologically healthy river corridor (see Table 1). Fundamentally, it covers the presence of natural structures like sediments and water, channels and floodplains. They also include collections of hydrophilic riparian plants and wildlife that rely much upon the natural hydrologic regimes representative of the landscape $[15,16]$.

Wee and Wee Garden has been established for more than 30 years beside Maong River. The positive aspect is the river bank remains natural, without any concrete embankment like most of the modern construction does. This stabilizes the river bank and in turn helps in maintaining its swampy and moist soils favourable for grasses like napier grass (Pennisetum purpureum), torpedo grass (Panicum repens), wild yam (Colocasia esculenta) and other local wetland species (see Figure 4). Generally, the grasses signify a functioning riparian system. Although the richness of the biodiversity is not as high as in pristine state, a variety of wetland communities grow wild in this narrow strip of land. 


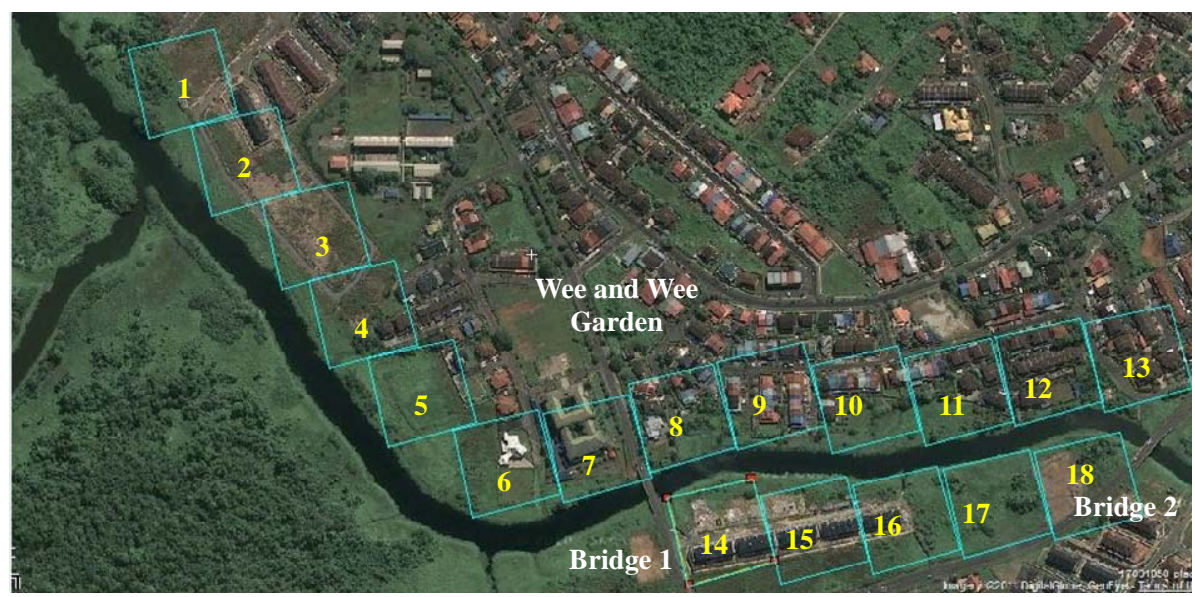

(a)

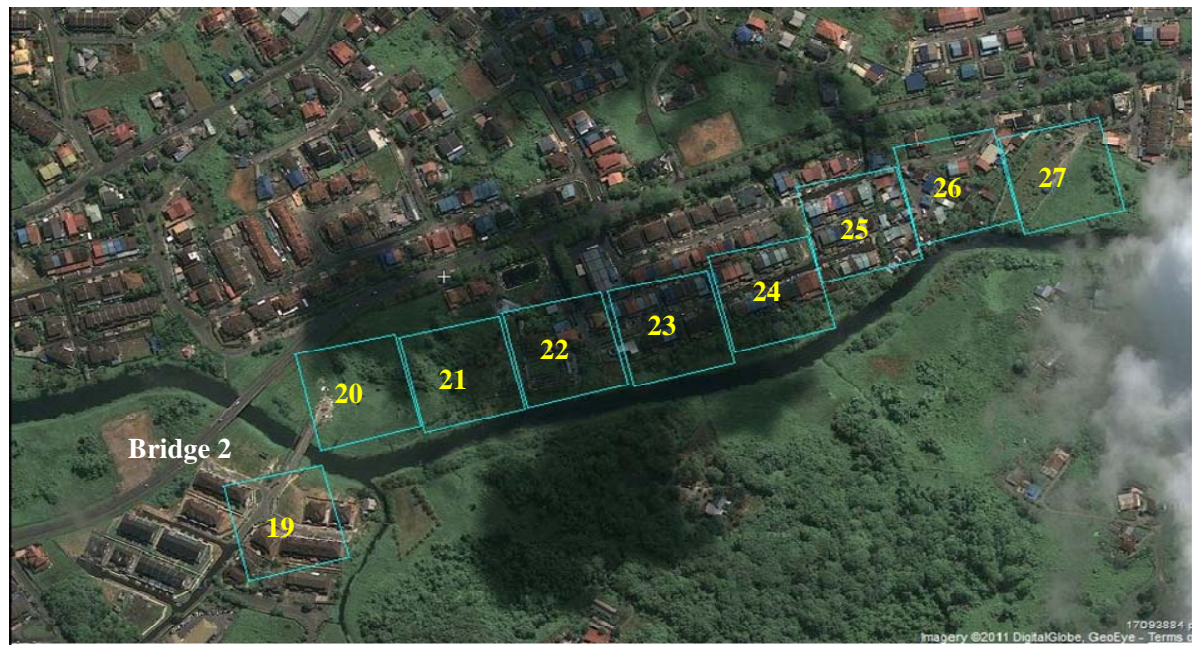

(b)

Figure 3. Study Area, (a) Western Zone and (b) Eastern Zone (http://www.wikimapia.org).

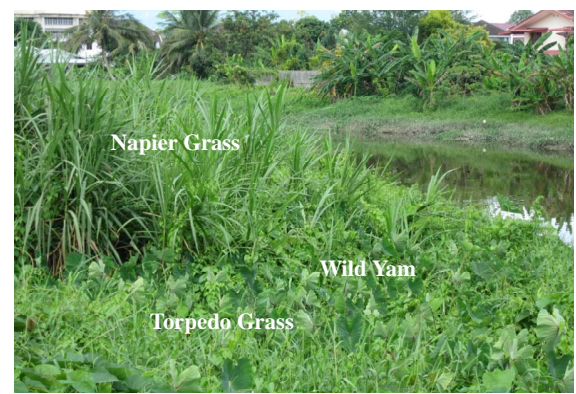

Figure 4. Grasses along Maong River.

\section{Field Measurement}

The three attributes - vegetation cover, human activities and groundwater level are chosen for they are rather ease to use and convenient to access. It is known that environmental features are continuous by nature and thus making it difficult to assess due to many intermingle factors within a system [17]. We present here a framework, while extracting only three parameters may seem fragmented, but in a way, it provides a straight forward means of interpreting complex riparian systems. The first two attributes can be measured using a geographical information system. It is a tool to produce mapping, exploring and analysing data of riparian features [18].

Vegetation cover - this is how much of the ground is covered by any sort of vegetation, of any life form. It is a crucial parameter to judge a riparian [19]. During field visit, it is seen and interpreted more easily to provide an early indication of riparian health and helping to understand the successional trend on a site. The average percentage for vegetation among all polygons is $46 \%$. Superimposing PFC data on the vegetation cover in each polygon, it is found that the riparian renders to nonfunctioning as the vegetation cover is lessening to about $30 \%$ of coverage (see Figure 5).

Human activities like construction of houses, roads, bridges and other hard structures influence the conditions and functions of the adjacent riparian system. In each polygon, the remaining portions other than vegetation 
Table 1. Riparian health assessment.

\begin{tabular}{|c|c|c|c|c|c|}
\hline Polygon & $\begin{array}{c}\text { Adequate Amount of } \\
\text { Vegetation }\end{array}$ & $\begin{array}{c}\text { Presence of } \\
\text { Natural Structure }\end{array}$ & Stable Riverbank & Vegetation Diversity & Riparian Health Status \\
\hline 1 & $\sqrt{ }$ & $\sqrt{ }$ & $\sqrt{ }$ & $\sqrt{ }$ & Functioning \\
\hline 2 & $\sqrt{ }$ & & $\sqrt{ }$ & $\sqrt{ }$ & Functioning \\
\hline 3 & & & $\sqrt{ }$ & & Intermediate \\
\hline 4 & $\sqrt{ }$ & $\sqrt{ }$ & $\sqrt{ }$ & & Functioning \\
\hline 5 & $\sqrt{ }$ & $\sqrt{ }$ & $\sqrt{ }$ & $\sqrt{ }$ & Functioning \\
\hline 6 & $\sqrt{ }$ & $\sqrt{ }$ & $\sqrt{ }$ & $\sqrt{ }$ & Functioning \\
\hline 7 & & & & & Non-functioning \\
\hline 8 & $\sqrt{ }$ & & $\sqrt{ }$ & $\sqrt{ }$ & Functioning \\
\hline 9 & & & & & Non-functioning \\
\hline 10 & $\sqrt{ }$ & & $\sqrt{ }$ & $\sqrt{ }$ & Functioning \\
\hline 11 & $\sqrt{ }$ & & $\sqrt{ }$ & $\sqrt{ }$ & Functioning \\
\hline 12 & & & & & Non-functioning \\
\hline 13 & & & & & Non-functioning \\
\hline 14 & & & $\sqrt{ }$ & & Intermediate \\
\hline 15 & & & $\sqrt{ }$ & & Intermediate \\
\hline 16 & $\sqrt{ }$ & $\sqrt{ }$ & $\sqrt{ }$ & & Functioning \\
\hline 17 & $\sqrt{ }$ & $\sqrt{ }$ & $\sqrt{ }$ & & Functioning \\
\hline 18 & $\sqrt{ }$ & $\sqrt{ }$ & $\sqrt{ }$ & & Functioning \\
\hline 19 & & & & & Non-functioning \\
\hline 20 & $\sqrt{ }$ & $\sqrt{ }$ & $\sqrt{ }$ & $\sqrt{ }$ & Functioning \\
\hline 21 & $\sqrt{ }$ & $\sqrt{ }$ & $\sqrt{ }$ & $\sqrt{ }$ & Functioning \\
\hline 22 & & & $\sqrt{ }$ & & Intermediate \\
\hline 23 & & & $\sqrt{ }$ & & Intermediate \\
\hline 24 & & & $\sqrt{ }$ & & Intermediate \\
\hline 25 & & & & & Non-functioning \\
\hline 26 & & & & & Non-functioning \\
\hline 27 & $\sqrt{ }$ & $\sqrt{ }$ & $\sqrt{ }$ & & Functioning \\
\hline
\end{tabular}

Note: If no $\sqrt{ }$, non-functioning; If 1 to $2 \sqrt{ }$, intermediate; If 3 to $4 \sqrt{ }$, functioning.

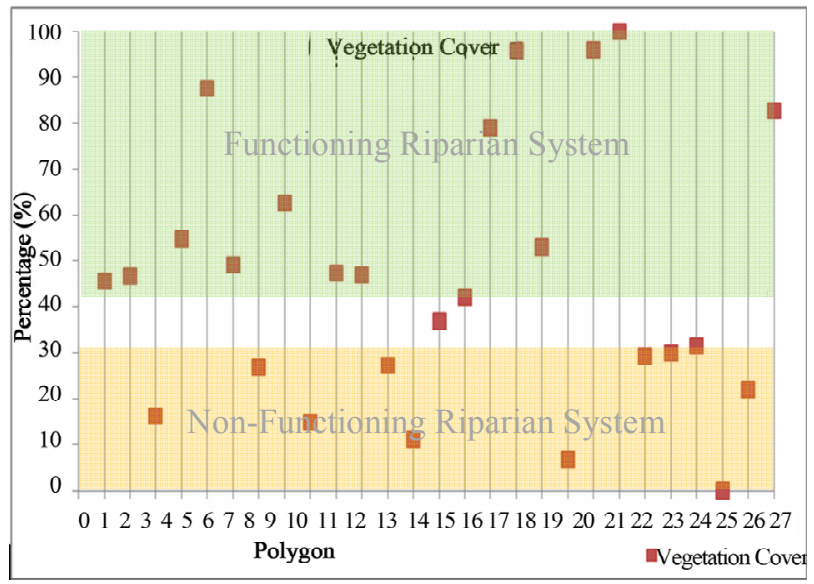

Figure 5. Vegetation cover and PFC data sets.

cover are lumped as human activities. The average percentage of human activities is $54 \%$, about $8 \%$ higher than vegetation cover. It is found that the riparian degrades to non-functioning when the human activities are approach- ing $70 \%$ of land coverage (see Figure 6).

From the aspect of hydrology, groundwater level is one important factor as riparian vegetation relies much on the groundwater table $[20,21]$. On-site tests have been carried out. The apparatus involved perforated pipe with adequate diameter, post hole digger, hammer and measuring tape. The pipe is inserted into the soil at a distance $2.5-3.0 \mathrm{~m}$ away from the water edge allowing the shallow groundwater to flow into the pipe, then lifted up to notice the level of water line from the ground surface (see Figure 7). Average reading for each polygon is plotted (see Figure 8). Comparing to PFC data set, it is observed that when the groundwater level from ground surface is $20 \mathrm{~cm}$ or higher, the system in place is no longer functioning. About $60 \%$ of the polygons are functioning with groundwater level around $15 \mathrm{~cm}$ from the ground surface.

Rearranging all data sets together, it shows the big picture of how much the altered riparian system under study adapted to changes (see Table 2). Riparian health 
Table 2. Comparison of data.

\begin{tabular}{|c|c|c|c|c|}
\hline $\begin{array}{c}\text { Vegetation Cover } \\
(\%)\end{array}$ & $\begin{array}{c}\text { Human Activities } \\
\text { (\%) }\end{array}$ & Groundwater Level & Riparian Health Status & Remark \\
\hline 100.00 & 0.00 & High & Functioning & \\
\hline 95.99 & 4.01 & High & Functioning & \\
\hline 95.7 & 4.30 & High & Functioning & \\
\hline 87.69 & 12.31 & High & Functioning & \\
\hline 82.69 & 17.31 & High & Functioning & \\
\hline 79.01 & 20.99 & High & Functioning & DESIRABLE \\
\hline 62.59 & 37.41 & High & Functioning & RANGE \\
\hline 54.84 & 45.16 & High & Functioning & Mean $32 \%$ \\
\hline 52.9 & 47.10 & High & Functioning & of Human \\
\hline 49.14 & 50.86 & High & Functioning & Activities \\
\hline 47.42 & 52.58 & High & Functioning & \\
\hline 47.04 & 52.96 & High & Functioning & \\
\hline 46.58 & 53.42 & High & Functioning & \\
\hline 45.68 & 54.32 & High & Functioning & \\
\hline 41.95 & 58.05 & Low & Intermediate & TOLERABLE \\
\hline 36.95 & 63.05 & Low & Intermediate & RANGE \\
\hline 31.59 & 68.41 & Low & Intermediate & Mean $66 \%$ \\
\hline 30.03 & 69.97 & Low & Intermediate & of Human \\
\hline 29.38 & 70.62 & Low & Intermediate & Activities \\
\hline 27.18 & 72.82 & Low & Non-functioning & \\
\hline 26.75 & 73.25 & Low & Non-functioning & \\
\hline 21.96 & 78.04 & Low & Non-functioning & DESTRUCTIVE \\
\hline 16.21 & 83.79 & Low & Intermediate & RANGE \\
\hline 15.07 & 84.93 & Low & Non-functioning & Mean $84 \%$ \\
\hline 11.23 & 88.77 & Low & Non-functioning & of Human \\
\hline 6.59 & 93.41 & Low & Non-functioning & Activities \\
\hline 0.00 & 100.00 & Low & Non-functioning & \\
\hline
\end{tabular}

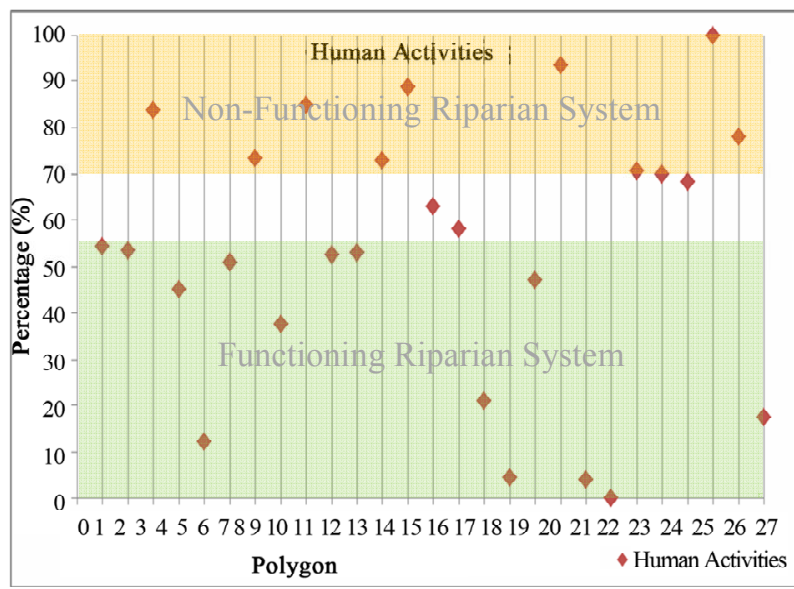

Figure 6. Human activities and PFC data sets.

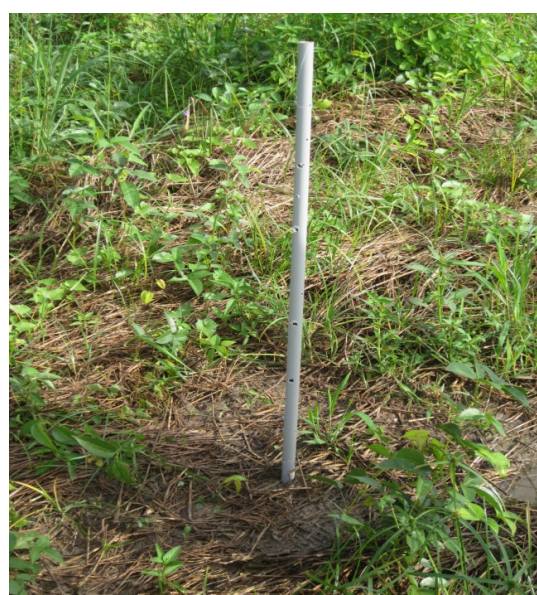

Figure 7. Shallow groundwater test. 


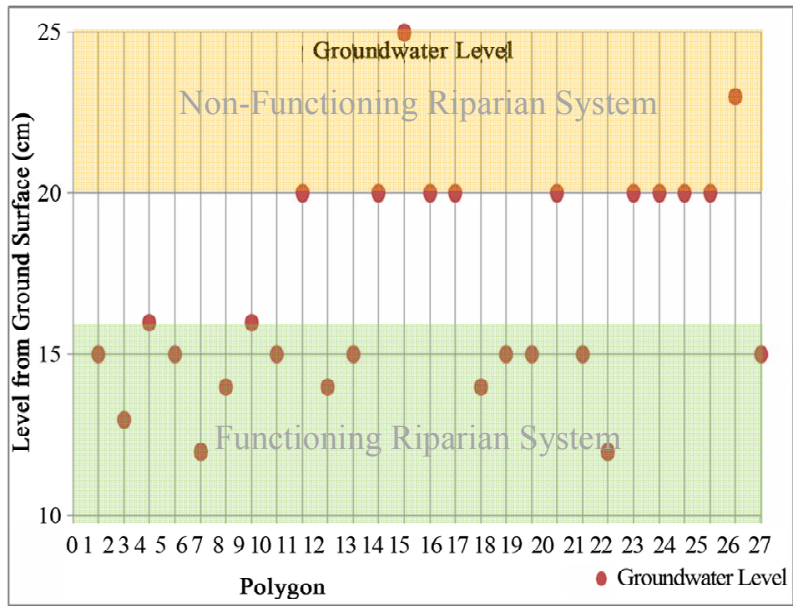

Figure 8. Groundwater level and PFC data sets.

conditions are further divided into three categories-desirable, tolerable and destructive ranges. In reality, human endeavours deem to pressure for more lands due to increasing needs for residential and transportation purposes. We suggest here, the tolerable range provides an opportunity to explore as indicator for tolerable human intervention in riparian zones.

From the findings, it is shown that most of the riparian zones along Maong River are categorized as healthy or functioning riparian systems. This means that the human-riparian interactions have been well managed all this while. Not only the residential around have made the effort, the local council has done their responsibility as well. By observing the conditions along the Maong River, it is still within an acceptable pollution level as there is no bad odour, garbage in the river and the turbidity of the river water is low.

\section{Conclusion}

Field investigation of an altered riparian zone has been conducted. Factors like vegetation cover, human activities and groundwater level have been taken into consideration. From the analysis of 27 polygons representative of the study site along Maong River, the riparian is generally good and in acceptable level, where $50 \%-60 \%$ of the areas are classified as functioning systems. This would not have happened if not the river is allowed of its natural banks to continue the cycles of decent hydrological regime and ecosystem. In other words, human-riparian interactions in this area have been well implemented throughout the year.

\section{Acknowledgements}

The authors express gratitude to opportunity, research, financial supports provided by the Universiti Malaysia Sarawak.

\section{REFERENCES}

[1] R. J. Naiman, H. Décamps and M. Pollock, "The Role of Riparian Corridors in Maintaining Regional Biodiversity," The Ecological Society of America, Ecological Application, Vol. 3, No. 2, 1993, pp. 209-212.

[2] M. Dubé, N. Nadorozny and A. J. Squires, "Development of the Healthy River Ecosystem Assessment System (Threats) for Integrated Change Assessments of Water Quality in Canadian Watersheds," In: J. Lundqvist, Ed., On the Water Front Vol. 2, Stockholm Int. Water Institute, Stockholm, 2011, pp. 31-40.

[3] Malaysian Ministry of Natural Resources and Environment (NRE), "Managing Biodiversity in the Riparian Zone," Malaysian Ministry of Natural Resources and Environment, Putrajaya, 2009.

[4] E. J. H. Corner, "Wayside Trees of Malaya," The Malayan Nature Society, Kuala Lumpur, 1988.

[5] L. S. Hamilton and D. H. Murphy, "Use and Management of Nipa Palm (Nypa fruticans, Arecaceae): A Review," Economic Botany, Vol. 42, No. 2, 1988, pp. 206-213. doi:10.1007/BF02858921

[6] F. W. Fong, "Perspectives for Sustainable Resource Utilization and Management of Nipa Vegetation," Economic Botany, Vol. 46, No. 1, 1992, pp. 45-54. doi:10.1007/BF02985253

[7] H. T. W. Tan, "A Guide to the Threaten Plants of Singapore," Singapore Science Centre, Singapore City, 1996.

[8] L. H. Liow, "Mangrove Conservation in Singapore: A Physical or Psychological Impossibility?" Biodiversity and Conservation, Vol. 9, No. 3, 2000, pp. 309-332. doi:10.1023/A:1008993417327

[9] H. P. Ritzema, "The Role of Drainage in the Wise Use of Tropical Peatlands," Carbon-Climate-Human Interaction on Tropical Peatland, Proceedings of the International Symposium and Workshop on Tropical Peatland, Yogjakarta, 27-29 August 2007, pp. 27-29.

[10] L. Fitch and N. Ambrose, "Riparian Area: A User's Guide to Health," Cows and Fish Program, Lethbridge, 2003.

[11] D. Prichard, H. Barrett, J. Cagney, R. Clark, J. Fogg, K. Gebhardt, P. Hansen, B. Mitchell and D. Tippy, "Riparian Area Management: Process for Assessing Proper Functioning Condition," Tech. Ref 1737, No. 9, USDI Bur. Land Manage, Denver, 1993.

[12] T. A. Ward, K. W. Tate, E. R. Atwill, D. F. Lile, D. L. Lancaster, N. McDougald, S. Barry, R. S. Ingram, H. A. George, W. Jensen, W. E. Frost, R. Phillips, G. G. Markegard and S. Larson, "A Comparison of Three Visual Assessments for Riparian and Stream Health," Journal of Soil and Water Conservation, Vol. 58, No. 2, 2003, pp. 83-88.

[13] T. D. Rich, "Using Breeding Land Birds in the Assessment of Western Riparian Systems," Wildlife Society Bulletin, Vol. 30, No. 4, 2002, pp. 1128-1139.

[14] D. Y. S. Mah and R. A. Bustami, "Conserving the Land: The Resilience of Riparian Wetlands and River Channels by a Fuzzy Inference System," Sustainability Science, Vol. 7, No. 2, 2011, pp. 267-272. 
doi:10.1007/s11625-011-0146-0

[15] S. V. Gregory, F. J. Swanson, W. A. McKee and K. W. Cummins, "An Ecosystem Perspective of Riparian Zones: Focus on Links between Land and Water," University of California, BioScience, Vol. 41, No. 8, 1991, pp. 540-551.

[16] Water Science and Technology Board (WSTB) and Board of Environmental Studies and Toxicology (BEST), "Riparian Areas: Functions and Strategies for Management," National Academy Press, Washington DC, 2002.

[17] D. Y. S. Mah, "Conservation of Sarawak Peat Swamp in an Urban Landscape by Fuzzy Inference System," Regional Environmental Change, Vol. 11, No. 2, 2011, pp. 307-310. doi:10.1007/s10113-011-0213-1

[18] W. H. Shayya, “An Introduction to ArcView ${ }^{\circledR}$ GIS," 2012. http://people.morrisville.edu/ shayyaw/ArcView/IntroAr cView.htm

[19] A. H. Winward, "Monitoring the Vegetation Resources in Riparian Areas," US Department of Agriculture, Forest Service, Rocky Mountain Research Station, Ogden, 2000.

[20] F. J. Swanson, T. K. Kratz, N. Caine and R. G. Woodmansee, "Landform Effects on Ecosystem Patterns and Processes," BioScience, Vol. 38, No. 2, pp. 92-98. doi: $10.2307 / 1310614$

[21] J. Stromberg, R. Tiller and B. Richter, "Effects of Groundwater Decline on Riparian Vegetation of Semiarid Regions: The San Pedro, Arizona," Ecological Applications, Vol. 6, No. 1, 1996, pp. 113-131. doi:10.2307/2269558 